\title{
Extracellular polysaccharides from Desulfovibrio desulfuricans and Pseudomonas fluorescens in the presence of mild and stainless steel
}

\author{
I. B. Beech', C. C. Gaylarde ${ }^{2}$, J. J. Smith ${ }^{3}$, and G. G. Geesey ${ }^{3}$ \\ 1 Lancashire Polyltechnic, Department of Applied Biology, Preston PR1 2TQ, UK \\ 2 City of London Polytechnic, Department of Biological Sciences, Old Castle Street, London, E1 7NT, UK \\ 3 California State University, Long Beach, Department of Microbiology, 1250 Bellflower Boulevard, Long Beach, CA 90840-4101, \\ USA
}

Received 20 August 1990/Accepted 8 November 1990

Summary. This communication reports the presence of polysaccharides in biofilms formed by pure and mixed cultures of Desulfovibrio desulfuricans and Pseudomonas fluorescens on mild and stainless steel surfaces. The results of colorimetric assays, indicating significant differences between the amounts of neutral sugars present in these biofilms, were supported by gas chromatographic (GC)-mass spectrophotometric and GC-flame ionisation detection analyses. Neutral sugars in biofilms grown on mild steel surfaces were identified and quantified, revealing glucose as a major carbohydrate followed by mannose and galactose in all types of biofilm. Extracellular polymeric substances (EPS) precipitated from bacterial cultures grown with and without steel surfaces were also analysed for their carbohydrate content. The influence of the surfaces present in the cultures on the amount and type of sugars released into the bulk phase was established. There was significantly more carbohydrate in EPS harvested from pure and mixed cultures of $D$. desulfuricans incubated mild and stainless steel coupons than in EPS obtained from coupon-free cultures. No significant difference in sugar quantities was observed in EPS precipitated from cultures of $\boldsymbol{P}$. fluorescens grown under different conditions (absence or presence of steel surfaces). The main carbohydrates identified in all types of EPS samples were mannose, glucose and galactose in order of prevalence.

\section{Introduction}

Many microorganisms produce exopolymers that promote adhesion to other cells or to inert surfaces (Costerton 1987). These exopolymers are frequently acidic polysaccharides (Geesey et al. 1988), which can compose a major proportion of biofilms including accumulations of microbial cells, extracellular polymeric sub- stances (EPS) and trapped debris on an immersed surface. The EPS produced by some bacteria have been shown to bind metal ions and hence can promote the corrosion of metals such as copper alloys (Jolley et al. 1988; Geesey et al. 1988) and steels (White et al. 1986; Ford et al. 1988). In addition to their innate aggressive activity towards metals, EPS also enhance corrosion by providing a matrix for the attachment of microbial cells to a metal surface. Close contact between bacteria and metal has been shown to be an important factor in determining the rate of corrosion (Gaylarde and Johnston 1980; Gaylarde and Videla 1987).

One of the most important groups of corrosion-causing organisms is the sulphate-reducing bacteria (SRB), a heterogeneous collection of anaerobic heterotrophs the economic influence of which has been particularly important in the oil industry (Hamilton 1985). These bacteria are known to cause corrosion by a number of mechanisms (Tiller 1983; Iverson 1987), but their ability, or otherwise, to produce EPS has not been recorded.

Members of the genus Pseudomonas have frequently been reported to produce exopolymers (White et al. 1985; Read and Costerton 1987; Jolley et al. 1988; Geesey et al. 1988) and these bacteria have been suggested to be primary colonisers of surfaces in aqueous environments (Corpe 1970). P. fluorescens has the ability to attach rapidly to the surfaces of mild and stainless steel (Beech and Gaylarde 1989) and in the presence of Desulfovibrio desulfuricans, a thick biofilm containing both species of bacteria builds up (Gaylarde and Beech 1989). Scanning electron microscopy suggests that EPS are produced by the bacteria in this biofilm (Moreno et al. 1990), but no work has been reported on the isolation and characterisation of these compounds.

This project sets out to isolate and analyse the EPS excreted into the environment by $D$. desulfuricans and $P$. fluorescens and to compare these with EPS within biofilms formed on mild and stainless steel coupons in the presence of these bacteria. 


\section{Materials and methods}

Organisms. D. desulfuricans subsp. desulfuricans New Jersey (NCIMB 8313) was grown as batch cultures in medium C of Postgate (1984) at $37^{\circ} \mathrm{C}$. Five-day-old cultures were used to provide the inoculum. $P$. fluorescens was isolated from a contaminated metal working fluid and identified by the Analytical Profile Index (API) 20 NE STRIP (API System S.A., Montalieu Varcieu, France). The organism was grown on nutrient agar plates at $24^{\circ} \mathrm{C}$ and 48-h cultures were used as inoculum.

Metal surfaces. Mild steel (British Standard 970) and stainless steel (British Standard 02134) coupons $(1.5 \mathrm{~cm} \times 10 \mathrm{~cm} \times 0.16 \mathrm{~cm}$ ) were sterilised dry by autoclaving in watertight containers. Before inoculation with bacterial cultures the coupons were immersed in $70 \%$ alcohol, flamed and placed vertically inside glass screw-capped flasks containing $135 \mathrm{ml}$ sterile medium $\mathrm{C}$ (five coupons per flask). The coupons were positioned to encourage biofilm growth on both sides.

Growth conditions. Cells of $D$. desulfuricans were harvested from broth cultures by centrifugation ( $500 \mathrm{~g}$ for $30 \mathrm{~min}$ ) and resuspended in sterile medium C. Cells of $P$. fluorescens were washed from the surface of the nutrient agar plate with sterile medium $C$. Cell suspensions of pure and mixed cultures of $D$. desulfuricans and $P$. fluorescens were adjusted by counting with an improved Neubauer haemacytometer to give a final concentration of $10^{5}$ cells $/ \mathrm{ml}$ in coupon-containing flasks and control coupon-free flasks. Flasks were set up in triplicate. Each set of three contained growth medium and either five stainless steel or five mild steel coupons or no coupons (control). Flasks were incubated for 7 days at $30^{\circ} \mathrm{C}$. The whole procedure was repeated three times.

EPS Samples. EPS were obtained from the bulk phase of pure and mixed batch cultures of $D$. desulfuricans and $P$. fluorescens grown aseptically for 7 days at $30^{\circ} \mathrm{C}$ in medium $\mathrm{C}$ containing mild steel and stainless steel coupons (fifteen coupons of each type per assay). Coupons were removed aseptically and cultures $(500 \mathrm{ml}$ per trial) were centrifuged for $30 \mathrm{~min}$ at $10,000 \mathrm{~g}$ to remove bacterial cells. The EPS were recovered from the supernatant by precipitating with $3 \mathrm{vol}$ isopropanol for $48 \mathrm{~h}$ at $4^{\circ} \mathrm{C}$. The precipitated polymer was redissolved in double distilled water $\left(\mathrm{ddH}_{2} \mathrm{O}\right.$ ), dialysed against $\mathrm{dd}_{2} \mathrm{O}$ overnight at $4^{\circ} \mathrm{C}$, lyophilised to dryness and stored at $-80^{\circ} \mathrm{C}$. EPS were also harvested from bacterial cultures $(500 \mathrm{ml})$ incubated without coupons and from precipitate obtained from $500 \mathrm{ml}$ of 7-day-old sterile medium C.

Biofilm samples. The mild steel and stainless steel coupons removed from the above cultures were immediately submerged in liquid nitrogen (to avoid formation of oxides) and freeze-dried. Lyophilised biofilms were removed from the coupon surfaces with a razor blade and the total biofilm from each set of fifteen coupons combined and stored at $-80^{\circ} \mathrm{C}$.

Scanning electron microscopy (SEM). Freshly withdrawn mild

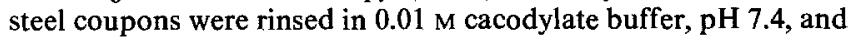
fixed in $0.5 \%(\mathrm{v} / \mathrm{v})$ glutaraldehyde at $4^{\circ} \mathrm{C}$ for $24 \mathrm{~h}$. They were then rinsed in cacodylate buffer and fixed for $3 \mathrm{~h}$ in $2.5 \%$ glutaraldehyde at $4^{\circ} \mathrm{C}$. After washing three times in cacodylate buffer, the coupons were dehydrated by passing through a graded series of reagent grade acetone $(30-100 \%)$ and frozen rapidly in liquid nitrogen prior to freeze-drying overnight. Dried coupons were cut into segments $(1.5 \mathrm{~cm} \times 3 \mathrm{~cm} \times 0.16 \mathrm{~cm})$, mounted on aluminium stubs, sputter-coated with gold and examined under a Hitachi (Tokyo, Japan) S450 scanning electron microscope at an accelerating voltage of $20 \mathrm{kV}$.

Removal of corrosion products from biofilm samples. Biofilms were treated to remove inorganic corrosion products by resuspending

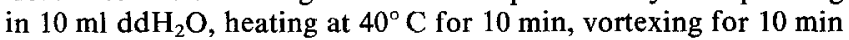
and centrifuging at $500 \mathrm{~g}$ for $30 \mathrm{~min}$. The supernatants were col- lected and the pellets extracted two more times. All washes were combined, centrifuged at $10,000 \mathrm{~g}$ for $30 \mathrm{~min}$ and the supernatants, now essentially free from metal oxides and sulphides, were lyophilised to dryness. Purified biofilms were stored at $-40^{\circ} \mathrm{C}$ prior to analysis.

Determination of sugars in EPS and in biofilm samples. Crude EPS and crude and treated biofilm samples were assayed for the presence of neutral hexoses (Dubois et al. 1956) and uronic acids (Blumenkrantz and Asboe-Hansen 1973). Reduction of sugars was performed by the method of York et al. (1985) using sodium borodeuteride and hydrolysis was conducted according to the procedure of Fazio et al. (1982). Derivatisation of the monomeric sugars using hydroxylamine hydrochloride and acetic anhydride followed the method of Quintero et al. (1990). Sugar standards (15) were prepared as $0.02 \mathrm{M}$ solutions and derivatised in the same way as samples. All procedures were performed using acidwashed glassware.

Gas chromatography $(G C)$. This was performed with a Varian (Sunnyvale, Calif., USA) model 3700 gas chromatograph with a flame ionisation detector (FID) and Varian CSD111 data system. Samples and sugar standards $(1 \mu \mathrm{l})$ were injected in triplicate into a polar $30 \mathrm{~m}$ fused silica capillary column, $0.25 \mathrm{~mm}$ ID (SP-2330, Supelco, Bellefonte, Pa., USA) using splitless injection. The temperature was programmed to rise from 160 to $210^{\circ} \mathrm{C}$ at a rate of $5^{\circ} \mathrm{C} / \mathrm{min}$, after which an isothermal period was held for $10 \mathrm{~min}$, followed by a temperature ramp to $225^{\circ} \mathrm{C}$ at a rate of $5^{\circ} \mathrm{C} / \mathrm{min}$, and this temperature held for $3 \mathrm{~min}$. Hydrogen was used as the carrier gas at a flow rate of $30 \mathrm{~cm}^{3} / \mathrm{min}$. The temperature of the injection port and the detector were controlled at $250^{\circ} \mathrm{C}$. The run was completed in $32 \mathrm{~min}$.

GC-mass spectrometry. GC-mass spectrometry was performed with a Hewlett-Packard (Palo Alto, Calif., USA) 5890 gas chromatograph and 5970 mass selective detector (MSD). Temperature programmes, MSD parameters and data analysis were controlled with a Hewlett-Packard 59970 MS Chemstation. Samples and sugar standards were injected as $1 \mu \mathrm{l}$ aliquots into a polar $30 \mathrm{~m}$ fused silica capillary column DB225-30N (J \& W Scientific, Rancho Cordova, Calif., USA), with splitless injection and $0.75-\mathrm{min}$ venting time. The temperature was set to rise from 160 to $210^{\circ} \mathrm{C}$ at $2^{\circ} \mathrm{C} / \mathrm{min}$, followed by an $18-\mathrm{min}$ isothermal period. The temperature was raised to $225^{\circ} \mathrm{C} / \mathrm{min}$ and held for $4 \mathrm{~min}$. The helium carrier gas was operated at a head pressure of $34.5 \mathrm{kPa}$ and a column flow rate of $30 \mathrm{~cm} / \mathrm{s}$. The injection port was held at $250^{\circ} \mathrm{C}$ and the detector at $280^{\circ} \mathrm{C}$. The mass spectrometer was autotuned with perfluorotributylamine and the electron multiplier voltage was $2000 \mathrm{~V}$. The instrument was used in the selective ion monitoring mode for highest sensitivity.

\section{Results}

\section{Characterisation of biofilms formed in steel coupons}

Figure 1a-c shows biofilms formed on mild steel coupons after 7 days of incubation with pure and mixed bacteria in medium C. Biofilms developed in the presence of $P$. fluorescens are scanty, few cells being visible above the cracked surface deposit (Fig. 1a). In contrast, biofilms of $D$. desulfuricans are thicker and comprise high densities of cells with abundant EPS, visible as fibres extending from the cells (Fig. 1b). Mixed culture biofilms appear equally if not more voluminous than those formed from pure cultures of $D$. desulfuricans. Cells and EPS fibres are to some extent obscured by amorphous corrosion products (Fig. 1c). 

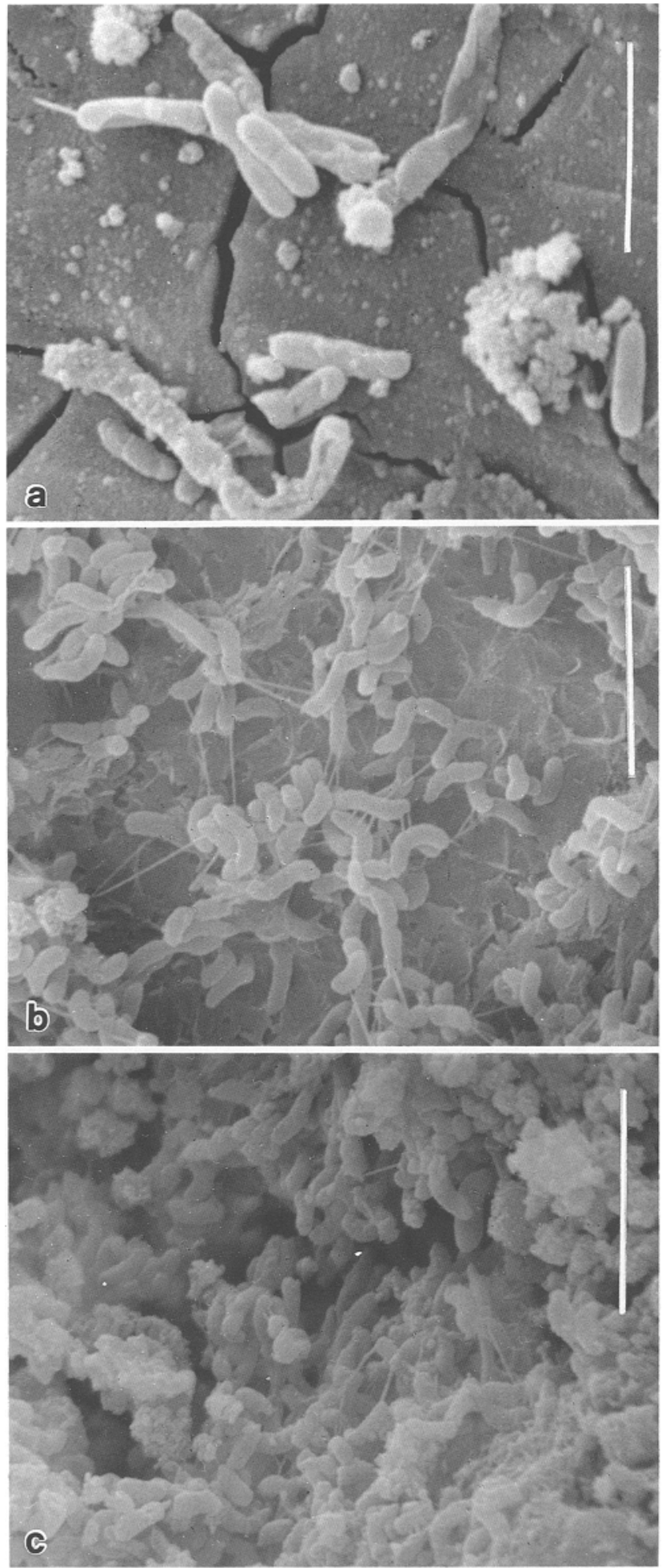

Fig. 1. Scanning electron micrographs of biofilms formed on mild steel coupons after 7 days incubation in medium $C$ (Postgate 1984) inoculated with a Pseudomonas fluorescens, b Desulfovibrio desulfuricans and c $P$. fluorescens and $D$. desulfuricans. Bar represents $5 \mu$
Table 1. Dry weight of biofilms formed on fifteen mild steel (MS) and fifteen stainless steel (SS) coupons incubated for 7 days with bacterial cultures in medium C (Postgate 1984)

\begin{tabular}{llr}
\hline Inoculum & \multicolumn{2}{l}{ Dry weight $(\mathrm{mg}+\mathrm{SD})$} \\
\cline { 2 - 3 } & MS & \multicolumn{1}{c}{$\mathrm{SS}$} \\
\hline $\begin{array}{l}\text { Pseudomonas fluorescens } \\
\begin{array}{l}\text { Desulfovibrio desulfuricans } \\
P . \text { fluorescens and }\end{array}\end{array}$ & $103.7 \pm 13.0$ & $7.9 \pm 3.0$ \\
$D$. desulfuricans & $118.7 \pm 20.0$ & $10.1 \pm 1.0$ \\
\hline
\end{tabular}

Table 2. Colorimetric estimation of neutral hexose content in crude and treated biofilms

\begin{tabular}{llll}
\hline Inoculum & \multicolumn{2}{l}{$\begin{array}{l}\text { Neutral hexose content } \\
\text { (\% of dry weight) }\end{array}$} & \\
\cline { 2 - 3 } & MS & SS \\
\hline $\begin{array}{l}\text { Crude } \\
\text { biofilm }\end{array}$ & $\begin{array}{l}\text { Treated } \\
\text { biofilm }\end{array}$ & $\begin{array}{l}\text { Crude } \\
\text { biofilm }\end{array}$ \\
\hline $\begin{array}{l}\text { P. fluorescens } \\
\begin{array}{l}\text { D. desulfuricans } \\
\text { P. fluorescens and } \\
\text { D. desulfuricans }\end{array}\end{array}$ & 3.48 & 3.42 & 2.8 \\
\hline
\end{tabular}

Table 1 shows the dry weights of biofilms removed from mild steel (MS) and stainless steel (SS) coupons. There was no significant difference between the dry weights of 7-day-old biofilms formed by pure and mixed bacterial cultures on either MS or SS surfaces. However, the amount of biofilm recovered from SS coupons was significantly lower than that obtained from MS coupons in all cultures.

Table 2 shows the amount of neutral hexoses expressed as a percentage of the dry weight detected colorimetrically in crude and treated biofilm samples. Analysis of variance shows that there was a significantly greater amount of neutral hexoses in crude and treated biofilms recovered from pure and mixed cultures of $D$. desulfuricans compared to that in biofilms formed by pure cultures of $P$. fluorescens on MS coupons. There were significantly more neutral hexoses present in crude biofilm formed by Desulfovibrio on MS coupons than in that removed from SS coupons.

The amounts of uronic acid detected colorimetrically in biofilms formed on MS surfaces by pure and mixed bacterial cultures are listed in Table 3. Biofilm treatment did not influence the efficiency of uronic acid recovery. The amounts of uronic acids present in treated biofilms were similar to those detected in crude biofilms.

\section{Analysis of carbohydrates present in biofilms grown on $M S$ coupons by $G C-F I D$}

Neutral sugar composition of 7-day-old biofilms formed on MS coupons by pure and mixed cultures of $P$. fluorescens and $D$. desulfuricans is summarised in Ta- 
Table 3. Uronic acid content in crude and treated biofilms formed on MS coupons

\begin{tabular}{lll}
\hline Inoculum & \multicolumn{2}{l}{$\begin{array}{l}\text { Uronic acid } \\
\text { content }(\mu \mathrm{g} / \mathrm{mg})\end{array}$} \\
\cline { 2 - 3 } & $\begin{array}{l}\text { Crude } \\
\text { biofilm }\end{array}$ & $\begin{array}{l}\text { Treated } \\
\text { biofilm }\end{array}$ \\
\hline $\begin{array}{lll}P . \text { fluorescens } \\
\text { D. desulfuricans }\end{array}$ & 3,74 & 3.04 \\
$P$. fluorescens and D. desulfuricans & 5.03 & 4.69 \\
\hline
\end{tabular}

Table 4. Neutral carbohydrates present in biofilms recovered from fifteen MS coupons after 7 days of incubation with bacterial cultures

\begin{tabular}{llll}
\hline $\begin{array}{l}\text { Type of } \\
\text { sugar }\end{array}$ & \multicolumn{2}{l}{ Neutral carbohydrates $(\mu \mathrm{g} / \mathrm{mg} \pm \mathrm{SD})$} \\
\cline { 2 - 4 } & P. fluorescens & D. desulfuricans & $\begin{array}{l}\text { P. fluorescens } \\
\text { D. desulfuricans }\end{array}$ \\
\hline Rhamnose & - & $0.372 \pm 0.070$ & - \\
Mannose & $0.475 \pm 0.009$ & $0.630 \pm 0.004$ & $1.190 \pm 0.070$ \\
Glucose & $0.973 \pm 0.060$ & $0.927 \pm 0.020$ & $1.102 \pm 0.059$ \\
Galactose & $0.130 \pm 0.020$ & $0.602 \pm 0.040$ & $0.487 \pm 0.040$ \\
Xylose & $0.096 \pm 0.014$ & $0.180 \pm 0.002$ & - \\
Allose & - & $0.175 \pm 0.037$ & - \\
$\begin{array}{l}\text { Gulose } \\
\text { Ribose }\end{array}$ & $0.053 \pm 0.020$ & - & - \\
\hline $\begin{array}{l}\text { Total } \\
\text { sugar recovered } \\
\text { (mg } \pm \text { SD) }\end{array}$ & $0.199 \pm 0.020$ & $0.372 \pm 0.070$ & $0.313 \pm 0.070$ \\
\hline
\end{tabular}

- not detected

Table 5. Molar ratios of the main neutral sugars present in biofilms formed on MS coupons

\begin{tabular}{llll}
\hline Organism & \multicolumn{3}{c}{ Glucose : Galactose : Mannose } \\
\hline$P$. fluorescens & 1.0 & 0.1 & 0.5 \\
$D$. desulfuricans & 1.0 & 0.4 & 1.1 \\
Mixed cultures & 1.0 & 0.65 & 0.7 \\
\hline
\end{tabular}

ble 4. The total amount of neutral sugar present in biofilms removed from MS coupons was calculated from the values obtained for individual sugars.

Table 5 shows the molar ratios of glucose, mannose and galactose, the main sugars detected in all three types of biofilms. Glucose contributed $53 \%(\mathrm{w} / \mathrm{w})$ of the total sugars detected in biofilms of $P$. fluorescens, $29.5 \%(\mathrm{w} / \mathrm{w})$ for $D$. desulfuricans and $36 \%(\mathrm{w} / \mathrm{w})$ in biofilms from mixed populations. Mannose contributed $26 \%, 20 \%$ and $36 \%(\mathrm{w} / \mathrm{w})$ respectively. Rhamnose was found only in biofilms of $D$. desulfuricans and gulose was detectable only in biofilms of $P$. fluorescens.

Biofilms formed on MS surfaces by pure and mixed cultures of $D$. desulfuricans contained significantly more neutral sugar than biofilms developed on MS coupons in the presence of pure cultures of $\boldsymbol{P}$. fluores- cens. There was no significant difference in the amount of neutral sugars detected chromatographically between biofilms from pure and mixed Desulfovibrio cultures. The quantities of biomass removed from the SS coupons were too small to detect individual sugars by gas chromatographic analysis.

\section{Analysis of bacterial EPS released into the aqueous phase}

The weight of crude EPS harvested from the bulk liquid phase of pure and mixed bacterial cultures incubated for 7 days in the presence and absence of MS or SS coupons is shown in Table 6 . Analysis of variance indicates that there was no significant difference in the amount of polymer released from the respective bacteria into the bulk aqueous phase when SS or MS coupons were present or absent.

The amount of polymer obtained from Pseudomonas cultures was significantly greater than that recovered from the respective pure and mixed Desulfovibrio cultures when the organisms were grown in the absence of steel surfaces, or when SS surfaces were present. No significant difference in polymer levels was observed between the cultures containing MS coupons.

Results of GC-mass spectrometric and GC-FID analysis showing the composition of carbohydrates and molar ratios of the main sugars detected in EPS harvested from 7-day-old pure and mixed cultures of $D$. desulfuricans and $P$. fluorescens incubated with MS and SS coupons are presented in Tables 7 and 8, respectively. The quantification of neutral hexoses was performed only for peaks of certain height. This corresponded to the concentration of $0.05 \mu \mathrm{g}$ carbohydrate in $1 \mathrm{mg}$ sample. Peaks below the arbitrary height were not integrated and it was agreed to refer to these carbohydrates as trace amounts.

Analysis of neutral carbohydrates by GC-FID showed that mannose was the dominant sugar in all types of EPS samples, being especially prevalent in $D$. desulfuricans-containing cultures. The relative abundance of this sugar was, however, greatly decreased in

Table 6. Extracellular polymeric substances (EPS) recovered from culture medium

\begin{tabular}{lll}
\hline Inoculum & Sample type & $\begin{array}{l}\text { Weight of EPS } \\
(\mathrm{mg} \pm \mathrm{SD})\end{array}$ \\
\hline P. fluorescens & MS & $95.9 \pm 26.6$ \\
& SS & $79.2 \pm 16.6$ \\
& Coupon-free & $73.6 \pm 6.7$ \\
\hline D. desulfuricans & MS & $66.5 \pm 14.4$ \\
& SS & $68.0 \pm 26.1$ \\
& Coupon-free & $48.6 \pm 7.1$ \\
\hline P. fluorescens and & MS & $60.6 \pm 12.2$ \\
$D$. desulfuricans & SS & $55.1 \pm 3.4$ \\
& Coupon-free & $42.6 \pm 5.7$ \\
\hline
\end{tabular}


Table 7. Neutral sugars detected in free EPS recovered from pure and mixed bacterial cultures incubated for 7 days with and without steel coupons

\begin{tabular}{|c|c|c|c|c|c|c|c|c|c|}
\hline \multirow[t]{2}{*}{$\begin{array}{l}\text { Type of } \\
\text { sugar }\end{array}$} & \multicolumn{3}{|c|}{ P. fluorescens } & \multicolumn{3}{|c|}{ D. desulfuricans } & \multicolumn{3}{|c|}{$\begin{array}{l}\text { P. fluorescens } \\
D . \text { desulfuricans }\end{array}$} \\
\hline & MS & SS & $\begin{array}{l}\text { Coupon } \\
\text { free }\end{array}$ & MS & SS & $\begin{array}{l}\text { Coupon } \\
\text { free }\end{array}$ & MS & SS & $\begin{array}{l}\text { Coupon } \\
\text { free }\end{array}$ \\
\hline Rhamnose & $\operatorname{tr}$ & + & + & + & $\operatorname{tr}$ & + & - & - & - \\
\hline Mannose & + & + & + & + & + & + & + & + & + \\
\hline Glucose & + & + & + & + & + & + & + & + & + \\
\hline Galactose & + & + & + & + & + & + & $\mathrm{tr}$ & + & + \\
\hline Xylose & - & - & + & - & - & + & - & - & - \\
\hline Arabinose & + & - & + & - & - & - & $\operatorname{tr}$ & + & $\operatorname{tr}$ \\
\hline Altrose & - & - & - & - & + & - & - & $\operatorname{tr}$ & - \\
\hline Ribose & + & + & + & $\operatorname{tr}$ & $\operatorname{tr}$ & + & $\operatorname{tr}$ & $\operatorname{tr}$ & + \\
\hline
\end{tabular}

+ , detected amount (greater than, or equal to $0.05 \mu \mathrm{g} / \mathrm{mg}$ ); $\mathrm{tr}$, trace amount (less than $0.05 \mu \mathrm{g} / \mathrm{mg}) ;-$, not detected
Table 8. Molar ratios of the main neutral sugars present in free EPS samples

Cultures grown with MS coupons

\begin{tabular}{llll}
\hline & \multicolumn{3}{l}{ Glucose : } \\
\cline { 2 - 4 }$P$. fluorescens & 1.0 & 2.5 & 0.1 \\
$\begin{array}{l}\text { D. desulfuricans } \\
P . \text { fluorescens } \text { and }\end{array}$ & 1.0 & 12.0 & 0.2 \\
$D$. desulfuricans & 1.0 & 10.0 & $\mathrm{tr}$ \\
\hline
\end{tabular}

Cultures grown with SS coupons

\begin{tabular}{llcc}
\hline & \multicolumn{3}{l}{ Glucose : } \\
\hline P. fluorescens & 1.0 & 3.0 & 0.03 \\
$\begin{array}{l}\text { D. desulfuricans } \\
\text { P. fluorescens and }\end{array}$ & 1.0 & 5.0 & 0.20 \\
$D$. desulfuricans & 1.0 & 3.5 & 0.10 \\
\hline
\end{tabular}

Cultures grown with no coupons

\begin{tabular}{llcl}
\hline & \multicolumn{3}{l}{ Glucose : Mannose : Galactose } \\
\cline { 2 - 4 } $\begin{array}{lll}\text { P. fluorescens } \\
\text { D. desulfuricans }\end{array}$ & 1.0 & 3.0 & 0.02 \\
$P$. fluorescens and & 1.0 & 11.5 & 0.40 \\
\begin{tabular}{l} 
D. desulfuricans \\
\hline
\end{tabular} & 1.0 & 11.0 & 0.10 \\
\hline
\end{tabular}

Table 9. Neutral sugar content of EPS obtained from bacterial cultures incubated for 7 days with and without steel coupons

\begin{tabular}{lll}
\hline Organism & Sample type & $\begin{array}{l}\text { Neutral sugar content } \\
\text { of EPS } \\
\text { (mg } \pm \text { SD) }\end{array}$ \\
\hline$P$. fluorescens & MS & $6.65 \pm 1.85$ \\
& SS & $4.86 \pm 1.02$ \\
& Coupon-free & $5.64 \pm 0.52$ \\
\hline D. desulfuricans & MS & $1.24 \pm 0.27$ \\
& SS & $0.84 \pm 0.28$ \\
\hline Pfluorescens and & MS & $0.39-0.04$ \\
$D$. desulfuricans & SS & $2.74 \pm 0.55$ \\
& Coupon-free & $2.28 \pm 0.14$ \\
& $1.63 \pm 0.30$ \\
\hline
\end{tabular}

EPS from SS-containing cultures when compared with the other two samples.

The total amount of neutral sugars detected chromatographically in EPS recovered from bacterial cultures is given in Table 9. Analysis of variance shows that significantly more neutral sugar was present in EPS recovered from cultures of $D$. desulfuricans incubated with MS or SS coupons compared with that from couponfree cultures. This observation is also true for EPS samples obtained from mixed bacterial cultures. There was no significant difference in the neutral sugar content of EPS precipitated from $P$. fluorescens cultures incubated with or without steel coupons. The quantity of neutral sugars in EPS from $P$. fluorescens was significantly higher than the level of sugars in EPS of either pure or mixed cultures of $D$. desulfuricans regardless of the culture conditions. The content of neutral sugars in all types of EPS harvested from $D$. desulfuricans cultures was significantly lower than that obtained from mixed cultures.

\section{Analysis of carbohydrates in precipitate from sterile medium $C$}

The percentage of neutral hexoses detected by colorimetric assay in $6.5 \mathrm{mg}$ dry weight of precipitate collected from $500 \mathrm{ml}$ of 7-day-old, sterile medium $\mathrm{C}$ was $40 \% \mathrm{w} / \mathrm{w}$. The types and quantities of sugars detected by GC-FID are presented in Table 10. Mannose and ribose were the main components of the medium $\mathrm{C}$ precipitate and they contributed $48 \%$ and $34 \%$ respectively to the total sugar amount. Glucose (7\% of total sugar) and galactose (11\% of total sugar) were also present.

The possible contribution of sugars detected in sterile medium $\mathrm{C}$ towards the total amount of sugar present in EPS recovered from bacterial cultures incubated with and without steel coupons is shown in Table 11. The possible contribution of sugar present in the precipitate from sterile medium $C$ towards the total level of sugar detected in free EPS samples varied from $1.8 \%$ $\mathrm{w} / \mathrm{w}$ to $30 \% \mathrm{w} / \mathrm{w}$. 
Table 10. Carbohydrates detected in precipitate from sterile medium $\mathbf{C}$

\begin{tabular}{ll}
\hline Type of sugar & Quantity $(\mu \mathrm{g} / \mathrm{mg} \pm \mathrm{SD})$ \\
\hline Mannose & $8.845 \pm 3.700$ \\
Glucose & $1.275 \pm 0.110$ \\
Galactose & $2.048 \pm 0.314$ \\
Ribose & $6.244 \pm 1.120$ \\
\hline Total & $18.312 \pm 5.244$ \\
\hline
\end{tabular}

Table 11. Possible contribution of sugar detected in precipitate from sterile medium $\mathrm{C}$ towards the total amount of sugar present in EPS recovered from bacterial cultures incubated for 7 days with and without steel coupons

\begin{tabular}{lll}
\hline Organism & Sample type & $\begin{array}{l}\text { Weight of sugar } \\
\text { from C } \\
(\%)\end{array}$ \\
\hline P. fluorescens & MS & 1.77 \\
& SS & 2.44 \\
& Coupon-free & 2.10 \\
\hline D. desulfuricans & MS & 9.59 \\
& SS & 14.16 \\
& Coupon-free & 30.50 \\
\hline P. fluorescens and & MS & 4.34 \\
$D$. desulfuricans & SS & 5.21 \\
& Coupon-free & 7.30 \\
\hline
\end{tabular}

\section{Discussion}

These results demonstrate unequivocally the ability of $D$. desulfuricans to produce extracellular polysaccharides. Furthermore, the excretion of polysaccharides is shown to be stimulated by the presence of steel surfaces (Table 9). The analysis of uninoculated medium $\mathrm{C}$ (Table 10) indicates that a variable amount of sugars, especially mannose and ribose, can be derived directly from the medium constituents. It is not possible to distinguish unmetabolised medium components from cell products. However, some comparisons may still be made. In previous work on exopolymer production by a Desulfovibrio sp. (Ochynski and Postgate 1963), paper chromatography was employed to identify mannose as the only neutral sugar in free EPS. For the SRB strain used in our study mannose also appears to be a dominating, but not the only, sugar in the free polymer. In the presence of MS coupons the exopolymer was particularly enriched in mannose when compared with that from SS cultures (Table 8). This difference in composition of polysaccharide stimulated by different types of metals has been noted previously by Ford et al. (1988). Although EPS of $P$. fluorescens is also rich in mannose, the proportion of this carbohydrate was not altered by the presence of steel surfaces (Table 8), and neither did $P$. fluorescens produce greater amounts of EPS in response to incubation with steel coupons (Table 9).
It has been suggested that the sugar composition of bacterial surface exopolymers is identical to that of polymers found in the liquid phase of the incubating medium (Kennedy and Sutherland 1987). The results of our investigation clearly show that under the experimental conditions chosen the composition of neutral carbohydrates from biofilms and from bulk phases differed (Tables 4 and 7). Whilst mannose was apparently the major sugar component of free EPS (Table 8), biofilm extracts revealed an abundance of glucose (Table 5 ). The ribose detected in these samples is likely to have originated from cell components, both the bacterial cells and the yeast extract that was a part of the culture medium.

No significant differences were detected in the amount of biofilm produced on any particular coupon recovered from 7-day-old pure cultures of $P$. fluorescens or $D$. desulfuricans, or from mixed cultures of the two species (Table 1). However, the amount of biofilm recovered from SS coupons was always significantly less than that from MS coupons from each of the 7-day-old cultures. The lack of a significant difference between the dry weights of biofilms from $P$. fluorescens and weights of biofilms from pure and mixed cultures of $D$. desulfuricans, in spite of the appearance of SEM micrographs, may be explained by the presence of inorganic material removed from the surface of the coupons during recovery of the biofilms.

The neutral sugar content of biofilms recovered from MS varied depending on species composition and was lower than the amounts obtained from SS coupons (Table 2). Mixed culture biofilms generally had a higher neutral hexose content than biofilms formed by each of the species grown as pure cultures. The biofilms developing in co-cultures of the two bacteria yielded a glucose:galactose ratio that was in between the ratios obtained from the biofilms of each of the pure cultures, indicating a contribution from both species.

Biofilms of both pure and mixed cultures of the two species on MS coupons contained traces of uronic acids when evaluated by colorimetric assay (Table 3 ). Biofilms of $P$. fluorescens, $D$. desulfuricans and co-cultures of the two species contained 3.7, 5.0 and $5.9 \mu \mathrm{g}$ uronic acid/mg dry weight, respectively. Uronic acids were not detected in free EPS, emphasising the differences in chemical composition between free and biofilm-bound polysaccharides.

In future studies it is hoped to determine the influence of these bacterial EPS on the corrosion of steel. Geesey et al. (1988) have shown that some bacterial EPS, but not others, can facilitate the corrosion of copper surfaces because of a high binding affinity for cupric ions. In early studies on microbial corrosion Corpe (1975) implicated microbial polysaccharides in the dissolution of metals. Exopolymers from $P$. atlantica have been shown to be aggressive to SS (White et al. 1985). However, apart from a direct effect, bacterial EPS could also influence corrosion indirectly. The formation of biofilm mediated by EPS production may lead to a high acid concentration at the surface thus promoting deterioration of metal. The demonstration of poly- 
saccharide production by a member of the sulphate reducers offers the possibility of determining yet one more mechanism by which this group of bacteria may induce corrosion of metal.

Acknowledgement. The authors wish to thank the Wain Trust of the Agricultural and Research Council for partial financial support to I. B. Beech.

\section{References}

Beech IB, Gaylarde CC (1989) Adhesion of Desulfovibrio desulfuricans and Pseudomonas fluorescens to mild steel surfaces. J Appl Bacteriol 67:201-207

Blumenkrantz N, Asboe-Hansen G (1973) New method for quantitative determination of uronic acids. Anal Biochem 54:484489

Corpe WA (1970) An acid polysaccharide produced by a primary film-forming marine bacterium. Dev Ind Microbiol 2:402412

Corpe WA (1975) Metal binding properties of surface materials from marine bacteria. Dev Ind Microbiol 16:249-259

Costerton JW (1987) Bacterial biofilms in nature and disease. Annu Rev Microbiol 41:435-464

Dubois M, Gilles KA, Hamilton JK, Rebers PA, Smith F (1956) Colorimetric method for determination of sugars and related substances. Anal Chem 28:1151-1159

Fazio SA, Uhlinger DJ, Parker JH, White DC (1982) Estimations of uronic acids as quantitative measures of extracellular and cell wall polysaccharide polymers from environmental samples. Appl Environ Microbiol 43:1151-1159

Ford TE, Maki JS, Mitchell R (1988) Involvement of bacterial exopolymers in biodeterioration of metals. In: Houghton DR, Smith RN, Eggins HOW (eds) Biodeterioration 7, Proceedings of the Seventh International Biodeterioration Symposium, Cambridge, June 1987. Elsevier Applied Science, Barking, UK, pp 378-384

Gaylarde CC, Beech IB (1989) Bacterial polysaccharides and corrosion. In: Gaylarde CC, Morton LHG (eds) Biocorrosion: Biodeterioration Society, Kew, UK, pp 85-98

Gaylarde CC, Johnston JM (1980) The importance of microbial adhesion in anaerobic metal corrosion. In: Berkeley RCW, Lynch JM, Melling J, Rutter PR, Vincent B (eds) Microbial adhesion to surfaces. Ellis Horwood, Chichester, pp 511-513

Gaylarde CC, Videla HA (1987) Localised corrosion induced by a marine vibrio. Int Biodeterior 23:91-104
Geesey GG, Jang L, Jolley JG, Hankins MR, Iwaoka T, Griffiths PR (1988) Binding of metal ions by extracellular polymers of biofilm bacteria. Water Sci Technol 20:161-165

Hamilton WA (1985) Sulfate reducing bacteria and anaerobic corrosion. Annu Rev Microbiol 39:195-217

Iverson WP (1987) Microbial corrosion of metals. Adv Appl Microbiol 32:1-36

Jolley JG, Geesey GG, Hankins MR, Wright RB, Wichlacz PL (1988) Auger electron spectroscopy and X-ray photoelectron spectroscopy of the biocorrosion of copper by gum arabic, bacterial culture supernatant and Pseudomonas atlantica exopolymer. Surface Interface Anal 11:371-376

Kennedy AFD, Sutherland IW (1987) Analysis of bacterial exopolysaccharides. Biotechnol Appl Biochem 9:12-19

Moreno DA, Ibars JR, Beech IB, Gaylarde CC (1990) Biofilm formation on mild steel coupons by Pseudomonas fluorescens and Desulfovibrio desulfuricans. Biofouling (in press)

Ochynski FW, Postgate JR (1963) Some biological differences between fresh water and salt water strains of sulphate-reducing bacteria. In: Oppenheimer $\mathrm{CH}$ (ed) Marine microbiology. Thomas, Springfield, Ill., pp 426-441

Postgate JR (1984) The sulphate-reducing bacteria. Cambridge University Press, Cambridge, UK

Quintero E, Ishida K, Gordon G, Geesey GG (1990) Comparison of reduction methods for gas chromatographic/mass spectrometric identification and quantification of uronic acids in acid polysaccharides. J Microbiol Methods 9:309-322

Read RR, Costerton JW (1987) Purification and characterisation of adhesive exopolysaccharides from Pseudomonas putida and Pseudomonas fluorescens. Can J Microbiol 33:1080-1090

Tiller AK (1983) Electrochemical aspects of corrosion: an overview. In: Microbial corrosion. Metals Society, London, UK, pp 54-65

White DC, Nivens DE, Nichols PD, Kerger BD, Henson JM, Geesey GG, Clarke CK (1985) The role of extracellular polymers in microbial adhesion and corrosion. In: Proceedings of the International Workshop on Biodeterioration, University of La Plata, Argentina, March 1985. Aquatec Quimica, São Paulo, pp 73-86

White DC, Nivens DE, Nichols PD, Mikell AT, Kerger BD, Henson JM, Geesey GG, Clarke CK (1986) Role of aerobic bacteria and their extracellular polymers in the facilitation of corrosion; use of Fourier transforming infrared spectroscopy and 'signature' fatty acid analysis. In: Biologically induced corrosion. National Assoc. of Corrosion Engineers-8, Houston, Tex., pp 233-243

York WS, Darvill AG, McNeil M, Stevenson TT, Albersheim P (1985) Isolation and characterisation of plant cell walls and cell wall components. Methods Enzymol 118:3-40 